\title{
Lukács and the aesthetic particularity of wage labor and the mediation of the state bureaucracy in 'I, Daniel Blake'
}

\section{BÁRBARA KATHERINE FARIS BIONDINI ${ }^{1}$ Rossi Henrique Soares Chaves ${ }^{2}$ JANAYNNA DE MOURA FERRAZ ${ }^{3}$}

\footnotetext{
${ }^{1}$ Universidade federal de Minas Gerais (UfMG) / Centro de Pós-graduação e Pesquisa em Administração, Belo Horizonte - MG, Brazil

${ }^{2}$ Universidade Federal de JUiz de Fora (UFJF) / CAMpus GoVernador VAladares, GoVernador VAladares - MG, BRAZIL

${ }^{3}$ Universidade Federal do Rio Grande do Norte (UFRN) / Departamento de CIÊNCIAS Administrativas, NATAL - RN, BRAZIL
}

\begin{abstract}
This essay aims to examine the film I, Daniel Blake, focusing on the treatment of director Ken Loach for the particularity of wage labor and the state bureaucracy in contemporary capitalism, supported by the treatment given to aesthetics by Lukács, which points out that the particularity is the central issue that involves the process of artistic creation and which we take as the starting point for a materialistic filmic analysis. We point out that the treatment given to categories has, in its genesis, the taking of the role of the director in approaching in a critical and committed way with reality, thus delineating his reflective potential. In portraying a singular reality experienced by a British worker subjected to a super-structural socioeconomic condition that has the universal element in the capital system, the way the particularity is portrayed allows transcending the work, which is a synthesis capable of reflecting the condition of exploitation and estrangement of the mediations on which workers are subjected in various parts of the world, as well as the role of the State. We conclude that materialist aesthetics is a robust and dense medium that can contribute to the research on contemporary sociability.
\end{abstract}

Keywords: Aesthetics. Particularity. Labor. State. Cinema.

\section{Lukács e a particularidade estética do trabalho assalariado e da mediação da burocracia do Estado em} 'Eu, Daniel Blake'

\section{Resumo}

Este ensaio objetiva perscrutar o filme Eu, Daniel Blake, tendo como foco o tratamento do diretor Ken Loach acerca da particularidade do trabalho assalariado e da burocracia do Estado no capitalismo contemporâneo, apoiados na estética oferecida por Lukács, o qual aponta ser a particularidade a questão central que envolve o processo de criação artística e a qual tomamos como ponto de partida para realizar uma análise fílmica materialista. Apontamos que o tratamento dado às categorias tem em sua gênese a tomada de partido por parte do diretor, uma vez que as aborda de maneira crítica e comprometida com a realidade, delineando, assim, o seu potencial reflexivo. Logo, ao retratar uma realidade singular vivida por um trabalhador britânico submetido a uma condição socioeconômica superestrutural que tem no regime do capital o elemento universal, a forma como a particularidade é retratada permite transcender a obra, que se constitui em uma síntese capaz de refletir a condição de exploração e estranhamento das mediações sobre as quais estão submetidos os trabalhadores em várias partes do mundo, bem como o papel do Estado. Concluímos que a estética materialista mostra-se um meio robusto e denso, que pode contribuir com as investigações da sociabilidade contemporânea.

Palavras-chave: Estética. Particularidade. Trabalho. Estado. Cinema.

\section{Lukács y la particularidad estética del trabajo asalariado y de la mediación de la burocracia del Estado en Yo, Daniel Blake}

\section{Resumen}

Este ensayo tiene como objetivo escrutar la película Yo, Daniel Blake, teniendo como foco el trato del director Ken Loach hacia la particularidad del trabajo asalariado y la burocracia del Estado en el capitalismo contemporáneo, apoyados en el trato dado a la estética por Lukács, quien indica que la particularidad es la cuestión central que envuelve el proceso de creación artística y la que tomamos como punto de partida para realizar un análisis fílmico materialista. Señalamos que el tratamiento dado a las categorías tiene en su génesis la toma de partido del director en su abordaje crítico y comprometido con la realidad, delineando así su potencial reflexivo. Al retratar una realidad singular vivida por un trabajador británico sometido a una condición socioeconómica superestructural que tiene en el régimen del capital el elemento universal, la forma como la particularidad es retratada permite trascender la obra, que se constituye en una síntesis capaz de reflejar la condición de explotación y extrañamiento de las mediaciones a las que están sometidos los trabajadores en varias partes del mundo, así como el papel del Estado. Concluimos que la estética materialista demuestra ser un medio robusto y denso que puede contribuir a las investigaciones acerca de la sociabilidad contemporánea.

Palabras clave: Estética. Particularidad. Trabajo. Estado. Cine. 


\section{INTRODUCTION}

Beyond the dusty discussion about the opposition between distraction (masses) and recollection (art lovers), cinema has been established as the most popular art of our time (REIS, 2015). Cinema has reached an important share among the different forms of artistic representation. If, on the one hand, it can be considered as a simple form of entertainment, on the other, it is a source of reflection on reality. According to the renowned and controversial French director Jean-Luc Godard, cinema would be the "truth at 24 frames per second." The statement expresses the potential of the 'seventh art' as a revelation of human manifestations, representing the experiences of social reality. This study is aligned with Godard and Lukács (1967, 2012), understanding that cinema may develop mirroring the reality as it is.

Studies on artistic productions have emerged in the field of administration (FERRAZ, MOURA-PAULA, BIONDINI et al., 2017; MORAES, GOMES and HELAL, 2016). Xavier and Carrieri (2014) acknowledge this phenomenon and encourage to think about the place given to the artistic object, avoiding abstract and subjectivist analyzes. The authors' suggestion is supported by the fact that artistic creation is not something neutral when considered as part of a superstructure that is shaped at the same time as it helps to shape the productive capitalist infrastructure. Therefore, art cannot be separated from the surrounding objective socioeconomic conditions; on the contrary, when ignoring the material relations that condition human life, the contradictions that govern today's sociability become opaque. Toledo, Lima, and Carrieri (2016), however, observe the absence of materialistic aesthetic analyzes in organizational studies.

Against this backdrop, our goal is to build a materialistic analysis of the film I, Daniel Blake, based on Lukacsian aesthetics. The analysis focuses on the director Ken Loach's perspective regarding the wage labor ${ }^{1}$ and the state bureaucracy in modern capitalism, observing how the film reflects these categories. For Reis (2015, p. 106, our translation), "[...] an ontological critique of cinema tries to understand how the interests of the hegemonic class adjust society's aesthetic-cultural education to their own objectives of social control." The investigation of such categories, therefore, plays a relevant role in organizational studies, as the critique of the way the bureaucracy is usually treated advances, also questioning the neutrality of the state. Regarding artistic aesthetics, the present reflection contributes to filling a gap in the field, as pointed out above, originated from the fact that modern art and other forms of subjectivist representation that separate form and content attribute an irrational character to the artwork. Moreover, artistic manifestations have great development potential so that that materialistic film analysis can contribute to the expansion of scientific investigations in Administration.

The study is based on Lukács' treatment of aesthetics $(1966,1967,1978)$. The author's analytical assumptions are used as a form of criticism of the film, as Cotrim (2013, p. 48, our translation) puts it: "[...] an assumption of all Lukacsian analysis of maturity: that there are works of art, therefore the analysis must start from the artwork itself." The author continues: "This means, on the one hand, not taking subjective appreciation as a starting point to apprehend the work and, on the other, recognizing that the essence of the aesthetic is not 'something originated or unique since the first moment" (COTRIM, 2013, p. 48 , our translation).

Lukács explains that the reflection on aesthetics has two moments: the apprehension of general aesthetic, philosophical principles, and the treatment of specific manifested forms such as music, literature, painting, and film. The new categories emerge from each objective, according to its peculiarity. Thus, Lukács (1978) points out that particularity is the central issue around the aesthetic creation process. The author points out twelve important connections to discuss aesthetic creation: 1) a more comprehensive characterization of the artistic forms; 2) manner and style; 3) technique and form; 4) aesthetic subjectivity and the category of particularity; 5) artistic originality and reflection of reality; 6) partisanship; 7) essence and phenomenon; 8) duration and transience; 9) individuality of the work and particularity; 10) content problems; 11) form problems; 12) art as humanity's self-consciousness of humanity. However, such connections are not established as a static method for analysis. They are suggestions of connections; they may not be the only ones or may not have hierarchy and complementarity (LUKÁCS, 1978). Therefore, this study starts with the peculiarities of the connections to build a single analysis.

\footnotetext{
${ }^{1}$ 'Wage labor' refers to the situation where the worker, who does not possess the production means, sells their labor power. In this case, the worker is conditioned to work in order to survive.
} 
It is important to emphasize that this film takes a different direction in comparison to the hegemonic film industry. It addresses everyday issues with a stance of denunciation and criticism of the economic system and the human condition. Reis (2005, p. 110, our translation, emphasis added by the author) points out that "[...] it must be carefully considered in the context of the ideological dispute that has long been fought in the film industry, the nature of what is apprehended and typified as resistance, opposition, or refusal." These characteristics have led I, Daniel Blake, to be an award-winning film (Palme d'Or at the Cannes Film Festival) and to obtain recognition by expert critics.

This article presents a brief explanation about aesthetics and discusses the centrality of the notion of 'particularity' in Lukács aesthetics, seeking to confront the film with the categories of the philosophy of art in Lukács. Subsequently, the article presents an analysis of the film, followed by final considerations.

\section{Aesthetics and arts}

For Lukács (1966), aesthetics - more specifically, art - is a form of manifestation of the reflection of reality, a form, among so many others, resulting from the relations between human beings and real life. As stated by Marx (2004, p. 110, our translation), the development of the five senses, i.e., the human sensibility, is "[...] a work of the entire history of the world so far." Therefore, aesthetic perception is connected to the production of life in its objectivity and subjectivity, especially when the form shifts from daily activity to a means of self-perception of the human race - or human kindness - according to Marx's terminology. In Lukács (1966, p. 24, our translation), art is understood as a social phenomenon, because: "art is a product of social evolution, such as work, science, and all human social activities. It is a product of the human that becomes human through their work." According to Cotrim (2013, p. 49, our translation), "[...] for Lukács art is a way for humans to appropriate the world, that is why it is mimetic, it is a historically developed social form whose peculiarity responds to human needs that are different from those needs addressed by other forms used to appropriate the world."

About forming sensibility, Marx (2011, p. 62-63, our translation) states:

[...] within the realm of the arts are possible only at an undeveloped stage of artistic development. If this is the case with the relation between different kinds of art within the realm of art, it is not surprising that it is also the case in the relation of the entire realm to the general development of society.

Marx (2011) uses Greek art to explain that this type of art was still considered beautiful in the nineteenth century (the period when Marx wrote these reflections), even though there were many differences in society's condition of reproducing life, between the period where Marx lived and the times when mythological gods explained the world. Although understanding that a work such as the Odyssey could not be produced under current conditions, the impression obtained by being in contact with such work remains, because "[...] The charm of their art for us is not in contradiction to the undeveloped stage of society on which it grew. [It] is its result, rather, and is inextricably bound up, rather, with the fact that the unripe social conditions under which it arose, and could alone arise, can never return" (MARX, 2011, p. 64).

Beauty is related to the fact that the history of art represents the very engendering of human kindness. In this case, although the socio-historical conditions of the production of Greek art no longer exist, it still awakens the senses, because it reflects the conditions that made room for the development of human relations' complexities. Thus, although the particularity of that time was over, looking for similarities between the undeveloped and the most developed complex - which are real, even if these similarities do not totally materialize - allows to produce an explanatory identity that corresponds, for example, to questions humans ask since those times: "where do we come from?" and "where are we going?" Greek art, therefore, is still dear to us both for the socio-historical conditions under which it was built, and also for the fact that it represents the childhood of humanity (MARX, 2011). It is noteworthy that there is not necessarily a correspondence between the degree of development of the productive forces and the artistic manifestations. In other words, universality is not linked to a potential individual's transcendence, but to the historicity of a time of humanity in which explanations of the things of the world came from imagination and creativity and not from science.

Based on Marx's and Lukács' aesthetics, it is possible to say that the appreciation of beauty is closely linked to the reproduction of life. Throughout history, with the development of the productive forces, the human senses change, and production, 
distribution, and consumption of art also change. Nowadays, as social relations are guided by capital, there is the contradiction that involves the work instruments and techniques because, on the one hand, there are more possibilities for artistic creations; on the other, the strangeness of these relations is the basis for the production of identically reified artworks.

Cinema here is considered as an artistic expression, corroborating Lukács' (1967) comprehension toward the seventh art. Cinema, unlike literature or painting, is reproducible. Actually, the characteristic of being reproducible is a condition. Cinema is an art form whose production is born focused on mass consumption.

Wellen (2016, p. 78, our translation) points out another important aspect: "[...] it is a fact that cinema can be considered the art of the director. The director leads and manipulates the central meaning of the films. They are involved in various parts of the production process, from casting to cutting and editing." However, this cannot be the only perspective, as Rosenfeld (2013) observes. Particularly nowadays, even though a film has the potential to represent reality, the major Hollywood film studios are not usually interested in aesthetic intentions and sometimes disregard the artistic phenomenon, since these are not their main stimuli to produce a film.

Paço-Cunha (2011, p. 2, our translation) indicates that "[...] through the mediation of productive forces, the aesthetic characteristics turn into a productive force of capital, a mode of being of capital in its relationship with the work it employs productively." This is evident when the 'commodity' role of films is analyzed. Thus, like all merchandise, the marketing aspects - which can increase sales - are highlighted, especially for the big studios that invest the capital necessary for the production and distribution of films. These studios "[...] are not, therefore, opposed to a moderate dose of aesthetic elements, but such aspects are subordinated to other interests, generally alien to art" (ROSENFELD, 2013, p. 35, our translation). The next section discusses the issue of particularity.

\section{Particularities in Lukács Aesthetics}

For Lukács (1966), it is crucial to clarify the place of aesthetics within the entirety of human activities and feelings, considering the reality in which the element is observed. The Hungarian philosopher points out that the "everyday human behavior is beginning and ending at the same time of all human activity" (LUKÁCS, 1966, p. 11, our translation). He uses an analogy, saying that everyday life is like a great river from which superior forms emerge to reproduce the reality, and, therefore, reproduce science and art. In this sense, science and art emerge from the impositions of social life, and they directly influence human life, again flowing into the stream of everyday life (LUKÁCS, 1966). The practical needs of human beings manifest in everyday life. Therefore, when observing the final result of artistic and scientific works, it is necessary to study the social needs that provoked and triggered their creation. For the author, this task can only be performed if it starts from the social genesis and human life because this is the only way to obtain the categorical peculiarities of the reality the human being seeks to reflect in the forms of art and science. The art that can reflect the species character, particularly, is a form that presents this anthropomorphic and materialistic nature.

When observing the aesthetic reflection in connection with other ways the individual reflects, Lukács (1966) understands that reality is composed of a multiple of interrelated determinations. Each aesthetic phenomenon has an objective essence, which is the result of a real, social, and historical process that has incisive determinations. Thus, it is impossible to conceptualize aesthetics apart from the whole compound in which it is inserted. This is the reason why Lukács relates aesthetics with science, ethics, and religion. Also, the influence of Marxian analysis through historical materialism is crucial to study the genesis and development of the arts, i.e., it is necessary to address the problems of aesthetics based on the historical particularities and determinations.

Lukács (1978) explains the central role of particularity in aesthetic analysis, where art assumes its form, and it is possible to verify whether the artist's work corresponds to the objective materiality as intended, understanding how the relationship between artistic expression and representation is coherent with the reality of daily life. The 'particular' also has the potential to reveal the relationship between a given social situation (singular) and a given productive condition (universal).

The particular, the singular, and the universal originate from immediacy, in everyday life, in constant mutual movement. In this sense, art, in its reflective originality, is an objective reflection of this particular synthetic movement between the singular 
and the universal, each particularity being expressed in a work of art in a unique way, considering that its field is formed of several determinations present in objectivity. Lukács (1978, p. 161, our translation) points out that:

As in the gnosiological reflex, the aesthetical aims to understand, discover, and reproduce, with its specific means, the entirety of reality in its explicit richness of contents and forms. Decisively changing $[\ldots]$ the subjective process, it [the aesthetical reflex] causes qualitative changes in the reflexive image of the world. The particularity is fixed in such a way that it can no longer be overcome: the formal world of the works of art is based on this particularity. The process by which categories are resolved and transformed into one another changes: particularity appears always to surpass both singularity and universality.

Overcoming singularity and universality within particularity, according to Lukács (1978), does not have to do with the extinction of these forms but rather to a synthesis that conserves these two movements overcoming them in the particular aesthetic movement. It is precisely how the singular and the universal are objectified in the work of art that will define its level of effectiveness in expressing the complexes and mediations of human life, in instigating and promoting identification with those in contact. In the words of Lukács (1978, p. 164, our translation):

The greater the artist's knowledge of humans and the world, the more numerous the mediations they discover and (if necessary) follow to the extreme universality, and the more marked will be this overcoming. The greater their [the artist] creative force, the more sensitively they will retransform the discovered mediations into a new immediacy, concentrating them organically on it: they will form something particular from something singular.

According to Lukács (1978), the greatness of a work of art is in its true content. It is in how the art stands against reality. The artist's choices are decisions made within a range of many others placed on particular objectivity, on social wholeness. A work of art takes shape around the particularity chosen by the author, the singular and the universal will be portrayed at specific moments. However, the final result that reveals the unity of work must be related to the particularity reflected by the artist.

Thus, art is a corollary of human production; once it is realized, and put in its final form before others, it will constitute a world of fiction. It is a creation that, in a unique and specific way, emphasizes and represents aesthetically, a particularity consisting of singular and universal questions. The result of a work of art is a reflection of reality, a specific aesthetic world. Therefore, each work of art can portray reality in specific ways, and it is also for this reason that those in contact with it cannot change it. At best, it can be rejected, and here comes the question of taste, of fruition in its individuality. However, this does not prevent, according to Lukács (1978), that criteria are created to measure the richness, receptivity, and depth with which a work reflected the objective reality, the world. Some of these criteria are the ordering, the hierarchy of contents and forms, the technique used, and the artist's position on the problems they sought to portray. These elements will be discussed below, based on a reflection about aesthetics and cinema.

\section{Aesthetics and Cinema}

Lukács (1967) discuss the art of cinema based on the general principles of his aesthetic reflection. The author points out that each image created and portrayed must be part of a previously established total unit. In this sense, a jumble of disconnected scenes is not an aesthetic expression, which introduces the importance of film directors and directors of photography. Aesthetics, therefore, emphasizes the contrast between the cinema and the other visual arts:

[...] this authenticity is only achieved if considered as the final result of the mimetic-artistic process of transformation, in the re-construction of reality; if the process of giving it a form fails, absolutely no authenticity is obtained; it has to be produced by purely aesthetic principles, creatively; it has to be confirmed in the immanence of the work of art; however, even the worst photograph already has - and cannot lose - authenticity (in the other sense of authenticity described). This clearly expresses the deep affinity, full of consequences, between everyday life and the film (LUKÁCS, 1967, p. 181, our translation). 
With the proximity between film and daily life, dialogue/language, photography, and portrayed scenes are directly related to the duration of a "real-time," i.e., in permanent movement. This appears in a condensed form, so it is possible to portray, in a short time, the link between present, past, and future. Due to its proximity to life - through the mimetic representation of reality ${ }^{2}$ - the film brings a tendency to reproduce the daily life from the multiple mediations that surround the human being, nature, and the entire social environment. Such engineering is the ultimate determinant of the aesthetic reflection of the film; in short, the reciprocal relationship between form and content.

Such notes allow us to understand the specific possibilities that cinema has in the field of aesthetics:

The authenticity of what was photographed produces a homogeneous medium that approximates the conformed 'world' to the world of everyday life, much more intensely than what is possible and admirable in the other arts. Films allow the coexistence of various forms of relationship between essence and appearance and promote an artistically legitimate collaboration: because for everyday life, it is obvious that objects of different structures, regarding the relationship between essence and appearance, exist simultaneously within the same reality and work on one another. The cinema transfers this peculiarity of the vision of everyday life to the homogeneous medium that gives it form and manages to, because it is an artistic transference, make these differences to result in important effects (LUKÁCS, 1967, p. 188, our translation).

Lukács (1978) discusses the human self-awareness potential of the aesthetic reflex regarding the artist's possibility, while in the individuality of their work, portray the issues of daily life and human individuality. It is justified to say that cinema can represent reality because of its potential to reflect it. It is essential, however, to highlight the role of ideology, since films can also be an effective means of ideological action (LUKÁCS, 1967):

[...] Because of the capitalism, the extraordinary ability of cinema to remunerate capital not only reveals the class that controls it ideologically but also makes it a fundamental instrument to adjust and maintain the teleological project of the bourgeoisie, given its capacity to reshape the world (REIS, 2015 , p. 105, our translation).

If the explanation of the degree of development of humanity is rooted in the productive forces, one can infer, that the most popular art of our times reflects the bourgeois ethos and its classist social status, that is, "[...] cinema recreates the image of the bourgeois in the world" (REIS, 2015, p. 108, our translation).

Nowadays, cinema is one of the most popular and affordable forms of art, given, among other factors, the emergence of the Internet and the advances in technology. If, on the one hand, its production and distribution are concentrated in large film studios and large film networks, constituting an effective instrument for the spread of bourgeois ideology; on the other hand, there is a higher potential to expose this ideology's contradictions than there has been at any other time.

\section{Analysis of the aesthetic particularity of the wage labor and of mediation of state's bureaucracy in I, Daniel Blake}

The film of the director Ken Loach, I, Daniel Blake, was released in 2016 and tells the story of Daniel Blake (Dave Johns), a 60 -year-old widowed woodworker who, after suffering a heart attack, is advised against returning to work by his doctors, and approaches the welfare system to receive his benefits.

Our materialistic film analysis consisted, at first, of demonstrating the connections suggested by Lukács to identify if there is an aesthetic particularity (which is neither static nor limiting) in the film - form, and content. In the second moment, the analysis explores the category of particularity in Lukács. The third moment consisted of watching the film repeatedly to extract categories directly from the object of study. The categories obtained were i) the function of the work for the human being, and ii) the state bureaucracy.

\footnotetext{
2 "Every image of a film is lived as a mimesis of a reality, guaranteed as such reality by the mere fact of being photographed: If one can photograph, it necessarily happened, and precisely in that way" (LUKÁCS, 1967, p. 199, our translation). Cotrim (2013, p. 19, our translation) mentions that aesthetic mimesis "[...] implies anthropomorphizing the photographic image, bringing it closer to 'what daily life looks like,' closer to what is created in the homogeneous mean, the artistic 'language' of the film," for the development and improvement of equipment and techniques.
} 
Critics of cinema say that the first scene of a film says a lot about the work. In I, Daniel Blake, even before an image appears, it is possible to hear Daniel answering a series of superficial questions related to the process of granting a welfare benefit ("can you turn on an alarm clock?"). The use of "superficial" here is explained by the fact that these questions had nothing to do with the heart attack the character in the leading role suffered. The character tried to reason with the attendant, but she ignored him and kept repeating the questions. Daniel then questions whether she was a doctor or a nurse. She replied that she was a "health professional" and is an employee of an American company hired by the English government for the service.

In a single scene, the film portrayed several situations such as the outsourcing of public services and the intensification of labor exploitation (what else would a "health professional" be other than an alternative to intensify the extraction of the surplus-value by creating professions where the "practice" means not treating the health?). The bureaucracy reduced Daniel to just an identification number among all the others. It made him an abstract individual ${ }^{3}-$ a citizen - whose answers must match the government's script, otherwise he would be denied access to a right (one of the citizen's rights that are proudly voiced by advocates of the welfare state).

In the subsequent scene, already aware that the benefit was denied (a decision informed through a letter), Daniel called the Department of Labor and Pensions. After 1h40min waiting on the phone - on a charged call - the character was informed that he did not have the score (established through 'questionnaire' to assess disability) required to receive the benefit. This was the start of his saga to obtain an appeal date.

The scene portrays the state bureaucracy. It is difficult not to feel empathy for Daniel when, during a long wait (listening to the background music of the telephone company and the lines "do not hang up, your call is important to us") the character engaged in routine activities, drinking coffee, washing the cup, complaining about the neighbor - as everybody eventually does to help pass the time. Observing the scene in its essence, however, other elements stand out, such as the fact that a paid call means that someone is making money from that situation. The state, in this case, was an intermediary between the exploiter (capital) and the exploited (worker). Daniel was no longer fit to work and still had to pay the phone company (probably private) in order to get assistance. The attempt to solve the problem via telephone was unsuccessful, as the procedure to access the benefit required that the character should wait to receive (passively) a call from the government department. Even with the denial letter in hand, the person on the other end of the line (a worker just as Daniel had been), says they could not help.

Daniel found it difficult to access his rights, whether because of the waiting queues, the need to use online systems that represent a barrier for people like him, who had no skills in technology, or because of the practice of transferring the person from one sector to another. At one point, a neighbor told Daniel that this was "part of the state plan for people to give up their rights."

When Daniel was finally granted the unemployment allowance, he was obliged to have a printed résumé and to prove that he was looking for a job for at least 35 hours a week. As he did not know how to write a résumé, he was directed to a workshop in which the instructor repeated phrases like "there is not enough work," "you need to stand out from the crowd," "prove you are a hard worker." In this case, the responsibility for unemployment was transferred to the worker. The worker also receives the burden of having to stand out from the others when looking for a job. The contradiction lies in the fact that, even if there is not enough work for everyone, those unemployed are the ones to blame for their situation, which is the logic of 'meritocracy' that permeates capitalist society.

The film portrays an implicit inversion between the machine and the individual, as the state uses information technology as a tool that excludes workers like Daniel from accessing a right. Would technology - a human creation - not be a tool to assist the subjects in reproducing life? In the case of Daniel, technology was shown as a matter of concern and suffering. It represented a barrier between the character and his benefit. The state should be responsible for building an ease relationship with the citizen, offering conditions according to the needs of the citizen when they are requesting no more than their due rights. The intention of this analysis is not advocating for the return of paper forms. The intention here is to emphasize the strangeness created within the capitalist sociability and, therefore, by the bourgeois state. The procedures are not designed to serve individuals. The individuals are forced to adapt to conditions created around the demands of machines.

\footnotetext{
${ }^{3}$ About the issue of the dichotomy between the citizen (the abstract individual) and the real individual, see Karl Marx "On the Jewish Question," and the work by Lukács "Ontology of Social Being II."
} 
As Daniel needed insurance, he made résumés, written by hand, and started to distribute them, until he got a call for a job interview. This situation turned into another reason for suffering because, embarrassed, he had to explain to the employer that the doctors did not clear him to work, but he had to keep distributing his résumé to be able to receive the unemployment allowance. In this conversation, the employer complains with Daniel for the time wasted. When returning to the department for an appraisal of the obligations related to the unemployment allowance, the character was not able to prove that he spent the required hours looking for a job, which resulted in a temporary cut of the payments. However, the department's employee instructed him that, by filling some other forms, entering other queues, making new requests, he could apply for "poverty assistance."

Once again, we see the state bureaucracy in operation. Those were the "denial goals" as the former department officials reported in interviews (SEYMOUR, 2017), which leads them to move on with some decisions, even though "against their will," to comply with state orders. These professionals ended up harming their own individuality, at the same time as they are impelled to dehumanize those they are serving. This occurs because there is a conflicting relationship between the citizen of public life and the individual of private life as if there were a real individual (Daniel) and an abstract individual (the benefit seeker who must get the required score to access their right). Thus the bourgeois state, which should be the manager of universal interests, emerged as the opposition to the citizen Daniel Blake, who was claiming his "universal rights."

In the course of the battle to get his benefits, Daniel went back to the department and, disbelieving that his case would have some progress, carries with him a can of spray paint. When leaving the premises, without a response for his appeal, the character rebelled and sprayed graffiti on the building's façade writing: "I, Daniel Blake, demand my appeal date before I starve and change the shite music on the phone." Daniel - who afterwards was arrested and taken to the police station but dismissed for having no background - sought to show that he was someone, a real individual. He, Daniel Blake, was one of those seeking his rights before the state. The character had found, through this action, a way to fight a system that made it impossible for him to acquire the basic survival conditions. Also, he registered in his graffiti the dissatisfaction with the time and money spent listening to "shite music" while waiting for ineffective service.

In the meantime, Daniel sold his furniture and private items to make money and keep up. He ends up physically weakening and moving away from friends, until one day he received the communication about his appeal date. When the judgment day came, Daniel asked the lawyer if he could say a few words at the time of the meeting, but suffered another heart attack and died before knowing the result of his case. The film demonstrates that the outcome for Daniel would not be different regardless if he struggled to access his allowance, or having to go back to work without medical authorization, risking his life.

Katie (Hayley Squires), an unemployed worker Daniel makes friends with, reads his letter during his funeral. Observing the statement by Marx and Engels (2007, our translation) "[...] language is the materialization of consciousness, which in turn is forged in practice and is a social product," an analysis of Daniel's letter will be provided below. The character's letter states:

I am not a client, a customer, nor a service user. I am not a shirker, a scrounger, a beggar, nor a thief. I am not a national insurance number, nor a blip on a screen. I paid my dues, never a penny short, and proud to do so. I don't tug the forelock, but look my neighbor in the eye. I don't accept or seek charity. My name is Daniel Blake; I am a man, not a dog. As such, I demand my rights. I demand you treat me with respect. I, Daniel Blake, am a citizen, nothing more, nothing less.

The feeling of strangeness and dehumanization under which Daniel suffered in his last days was evident. The incapacity to work and the submission to unreasonable situations to stay alive shook the subjectivity of the character. He felt treated as an animal rather than as the man, the woodworker, the person admired by friends and who had "paid his obligations, made his pennies, and was proud of it." In the eyes of the state, he was not important. The condition of state alienation was made clear in a situation where a universal right to be operated by the state entails a struggle from the beneficiary, considered a (abstract) citizen. He was, on the contrary, a man of flesh and blood, and he died before accessing what was his due right. Anyone who works for a living could be the leading character of this story. 


\section{FINAL CONSIDERATIONS: “WE, DANIEL BLAKE”}

This study analyzed the film I, Daniel Blake, focusing on the perspective of director Ken Loach about the particularity of wage labor and the state bureaucracy in modern capitalism, supported by Lukács' understanding of aesthetics. The first observation refers to the director's perspective, emphasizing the materialistic aspect present in Lukács' aesthetic particularity. Loach is known in the film industry for productions dealing with issues that distress human daily life. The director takes sides through criticism and denunciation of the precarious condition of the impoverished working class - their struggles for social rights and, above all, the capitalist logic of accumulation based on profit ${ }^{4}$. In I, Daniel Blake, the central theme is the dismantling of the English welfare state orchestrated by the demands of capital, especially after neoliberal policies. According to Loach (GUIMON, 2017, no page number, our translation):

[...] an inevitable process, is the way capitalism developed. Large corporations dominate the economy, creating a massive wave of poor people. The state must support them, but it does not want to or does not have resources. So, this creates an illusion that, if you are poor, it is your fault. Because you didn't fill out your résumé correctly or because you arrived late for an interview. They set up a bureaucratic system that punishes you for being poor. Humiliation is a key element in poverty. It steals your dignity and your self-esteem. The state contributes to humiliation with all this stupid bureaucracy.

The director expresses his intentions and the situations he wanted to portray in the film. Thus, it was not this study's intention to "unravel" a possible internal logic of the work, a logic different from what the director had already expressed; on the contrary, the director's perspective was the starting point for the analysis. Loach (SEYMOUR, 2017, no page number) says: "I challenge anyone to find a single word in that film that's not true." The director points out that he relied on hard research when producing the film, seeking to reflect reality accurately. This process involved interviews with current and former employees of job centers, who reported the situation in those places. During the press conference in Cannes, Loach said:

Finding the right tone for a film is important. For this one, we felt that the story was so strong that we had to be very simple, very clear, very economical, and that the film did not need any embellishment. Then, Robbie [Ryan, director of photography]... we talked about finding a style that was absolutely clear and plain and unadorned, without odd movements or anything else that could distract, or hinder the capacity of capturing the essence of the people in front of the camera, and of describing their situation in a plain and economical manner. There is a quotation from Berthold Brecht that I believe it is very good and guided us in more than one situation [...] "And I always thought the simplest of words must suffice. When I say what things are like it will break the hearts of all." And the thing that we tried to do is to say what things are like, because it not only breaks your heart, but it should make you angry (ESCOREL, 2017, no page number, our translation).

The second observation refers to the particularity of the work. The reality Loach portrayed does not differ, in general, from what happens in Brazil, given, for example, the current context, in which a set of political counter-reforms (introduction of a ceiling on public spending, labor, and social security reforms) has been proposed and implemented. This is a situation that indicates the universal aspect characterized by Lukács. For the author, "[...] the universal does not show in the existing reality in an isolated way or immediately, regardless of the objects and single relations. Therefore, it is necessary to obtain it [the universal] through the analysis of objects, relations, etc." (LUKÁCS, 2012, p. 43, our translation). From the UK to Brazil, these similarities in the objects analyzed to reflect the particularity of the cinema. They have the potential to be recognized in any country under the capital system.

The article exposed that, through the Lukacsian aesthetics, the peculiarity of the bourgeois state manifests in its condition as an intermediary of capital (purchase and use of technology, telephony, workshop); as a mediator of the surplus-value (managing the labor force as a commodity for capital); as manager of the public funds formed from taxes (outcome of the extraction of surplus value). In this case, the state did not intend to "give back" any part to the worker (difficulty in accessing

\footnotetext{
${ }^{4}$ Some examples: In Jimmy's Hall (2014), the director portrays the life of Jimmy Gralton, an important figure among the groups that originated the Communist Party of Ireland. In The Wind That Shakes the Barley (2006), Loach shows the organization of Irish workers in the movement for the independence of Ireland. In Bread and Roses (2000), the director shows the miserable day-to-day of a Mexican worker that migrates to the US looking for a better life and better working conditions and ends up engaging in the union struggles. Finally, in Route Irish (2010), Loach focuses on the financial interests of both the state and British companies in the War in Iraq.
} 
the benefits), thus raising the level of exploitation. The ideology of considering the "citizen" as a "client" to be served is blind to the vulnerability to which the "clients" are exposed (CHAVES, 2018). This is the particularity of the mediation of bureaucracy in the bourgeois state. Mészáros points out (2011, p. 108, our translation) that "[...] the highly bureaucratized modern state, with all the complexity of its legal and political machinery, arises from the absolute material necessity of the socio-metabolic order of capital and then - in the form of a dialectical reciprocity - it becomes an essential precondition for the subsequent coordination of the whole society." For Daniel, men, and women from the most impoverished part of the working classes, as well as the state bureaucracy, both act to perpetuate and deepen inequalities by contributing to the (re) production of capital.

Regarding the issue of wage labor, Daniel's health condition made him feel incapable when facing the people in his life. Daniel's labor force, the commodity he was selling for a long time, was now reflected to the state and its subjectivity as "outdated" and incapable. As for this particularity of the function of human labor in capitalism, Marx (2013, p. 120, our translation) indicates that "[...] as a creator of values of use, as useful labor, labor is a condition of the human's existence, independent of all social forms, eternal natural need for mediation of metabolism between human and nature and, therefore, of human life." Therefore, this particular condition of human work is the basis for building individual and collective subjectivities. In capitalist sociability, however, the centrality of labor replaces what would be the very concretization of human kindness in the process of alienation.

Concerning the method of materialistic analysis of the film based on Lukacsian aesthetics, it is possible to argue that, because of its ontological nature, it is limited to works of art whose internal nexus lies in objectivity; that is, to be considered an artistic element, the reality must 'act' through the singularity to represent the universal.

In his $1 \mathrm{~h} 40 \mathrm{~m}$ film (which is the same time Daniel waited during the phone call), Loach manages to convey the reproduction of material related to sensibility (such as photography, sounds, lights) and subjectivity (projection and reflection about something that one has already lived) of a worker as so many others. A worker who seeks to survive in a society where machines and numbers have become more important than human life. Although some may understand that the problem is the state, when observing the background, it is the capitalist sociability that produces all these relations. 


\section{REFERENCES}

CHAVES, R. H. S. A impotência da administração pública. 2018. Dissertação (Mestrado em Administração) - Faculdade de Ciências Econômicas, Universidade Federal de Minas Gerais, 2018. Available at: <https://repositorio.ufmg.br/bitstream/1843/BUOS-B3DL27/1/ disserta__o__vers_o_final_p_s_banca.pdf $>$. Accessed on: Nov. 16, 2018.

COTRIM, L. Apresentação de "Lukács e o Cinema". In: CHAGAS, R. (Org.). Cinema, Educação e Arte. Boa Vista: Editora da UFRR, 2013.

ESCOREL, E. Eu, Daniel Blake - corações despedaçados e revolta. Piauí, São Paulo, Jan. 20, 2017. Available at: <https://piaui.folha. uol.com.br/eu-daniel-blake-coracoes-despedacados-e-revolta/> Accessed on: July. 28, 2017.

FERRAZ, D. L. S. et al. Ideologia, subjetividade e afetividade nas relações de trabalho: análise do filme 'Que horas ela volta?'. Revista Brasileira de Estudos Organizacionais, v. 4, n. 1, p. 252-278, 2017.

GUIMON, P. Ken Loach: “O Estado cria a ilusão de que, se você é pobre, a culpa é". El País, Londres, 05 jan. 2017. Available at: <https:// brasil.elpais.com/brasil/2016/10/22/cultura/1477145409_049665. html> Accessed on: Aug. 02, 2017.

I, DANIEL Blake. Direção: Ken Loach. Produção: Rebecca O’Brien. Reino Unido: Wild Bunch, Why Not Productions, BBC Films, 2016. 1 DVD (100 min), widescreen, son. color.

LUKÁCS, G. Estética 1: la peculiaridad de lo estético. v. 1. Barcelona: Ediciones Grijalbo, 1966.

LUKÁCS, G. Estética 1: la peculiaridad de lo estético. v. 4. Barcelona: Ediciones Grijalbo, 1967.

LUKÁCS, G. Introdução a uma Estética Marxista: sobre a categoria de particularidade. Rio de Janeiro: Civilização Brasileira, 1978.

LUKÁCS, G. Ontologia do ser social I. São Paulo: Boitempo, 2012.

MARX, K. Manuscritos Econômico-filosóficos. São Paulo: Boitempo, 2004.
MARX, K. Grundrisse. São Paulo: Boitempo, 2011.

MARX, K. O capital: crítica da economia política: livro I: o processo de produção do capital. São Paulo, Boitempo: 2013.

MARX, K.; FRIEDRICH, E. A ideologia alemã. São Paulo: Boitempo, 2007.

MÉSZÁROS, I. Para além do capital: rumo a uma teoria da transição. São Paulo: Boitempo, 2011.

MORAES, A.F.G.; GOMES, D.C.; HELAL, D.H. Brazilian Jeitinho and Culture: an analysis of the films Elite Squad 1 and 2. RAM, v. 17, n. 3, p. 84-104, 2016.

PAÇO-CUNHA, E. As propriedades estéticas do trabalho como emanação de sua relação com o capital. In: ENCONTRO NACIONAL DOS PROGRAMAS DE PÓS-GRADUAÇÃO E PESQUISA EM ADMINISTRAÇÃO, 25., Rio de Janeiro, 2011. Anais... Rio de Janeiro; Anpad, 2011.

REIS, R. R. Ideologia e educação estética. Revista Crítica Marxista, n. 41, p. 105-122, 2015.

ROSENFELD, A. Cinema: arte e indústria. São Paulo: Perspectiva, 2013.

SEYMOUR, T. I, Daniel Blake 'doesn't represent reality'. The Guardian, New York, 10 fev. 2017. Available at: <https://www.theguardian. com/film/2017/feb/10/i-daniel-blake-doesnt-represent-reality-saysjobcentre-manager> Accessed on: Aug. 04, 2017.

TOLEDO, D. A. C., LIMA, O.; CARRIERI, A. P. Aesthetics and commoditylabor: Analysis of the lukacsian aesthetic properties in business magazines. RAUSP, São Paulo, v. 51, n. 2, p. 137-150, 2016.

WELLEN, H. "Melancolia", Lars von Trier e a humanidade à beira do abismo. In: WELLEN, H; WELLEN, E. Arte e Emancipação: ensaio sobre cinema. Maceió: Coletivo Veredas, 2016.

XAVIER, W. S.; CARRIERI, A. P. Concepções de uma estética materialista para uma arte transformadora: a superação do caráter abstrato na particularidade do trabalho artístico. Cadernos EBAPE.BR, Rio de Janeiro, v. 12, n. 3, p. 590-604, 2014.

Bárbara Katherine Faris Biondini

ORCID: https://orcid.org/0000-0002-5630-4738

PhD student in administration at the Federal University of Minas Gerais (UFMG), Belo Horizonte - MG, Brazil. E-mail: barbarakfbiondini@gmail.com

Rossi Henrique Soares Chaves

ORCID: https://orcid.org/0000-0003-2229-9472

PhD student in administration at the Federal University of Minas Gerais (UFMG); Substitute Professor at the Federal University of Juiz de Fora (UFJV), Campus Governador Valadares, Governador Valadares-MG, Brazil. E-mail: rossichaves@ hotmail.com

Janaynna de Moura Ferraz

ORCID: https://orcid.org/0000-0003-3668-4195

PhD in administration at the Federal University of Minas Gerais (UFMG); Adjunct Professor at the Federal University of Rio Grande do Norte (UFRB),

Department of Administrative Sciences, Natal-RN, Brazil. E-mail: jannaferraz@me.com 